\title{
Comparative Anthelmintic Efficacy of Caesalpinia Crista, Nigella Sativa and Oxfendazole in Broilers with Experimentally Induced Ascaridia Galli Infection
}

\author{
Syed Zahid Ali Shah", M.S.Khan, Sher Hayat Khan \\ Department of Clinical Medicine \& Surgery University of Veterinary \& Animal Sciences, Lahore \\ *Corresponding Author: zahidvet@hotmail.com
}

Copyright (C) 2014 Horizon Research Publishing All rights reserved.

\begin{abstract}
The study was conducted to explore the effect of two herbal drugs, Caesalpinia crista and Nigella sativa in comparison with Oxfendazole in broilers experimentally induced with Ascaridia galli infection .A total of 130 day old broiler chicks were divided into five groups i.e. A, B, C, D and $\mathrm{E}$ each group having 26 birds. Group $\mathrm{E}$ was kept as negative control, while all other groups were induced with experimental Ascardia galli infection on $15^{\text {th }}$ day. Group A was kept as positive control and groups $\mathrm{B}$ and $\mathrm{C}$ were treated with Caesalpinia crista and Nigella sativa as methanolic extract orally once @ $50 \mathrm{mg} / \mathrm{kg}$ body weight and group D was medicated with Oxfendazole @ $10 \mathrm{mg} / \mathrm{kg}$ body weight orally once on $25^{\text {th }}$ day post infection. On 25th day post infection before treatment 4 birds from each group were slaughtered, and worm count was done. The efficacy was confirmed by counting the worm, slaughtering all the bird on $30^{\text {th }}$ day post infection. The mean worm count was significantly different $(p<0.05)$ between the treated and non treated groups. The efficacy of the plant extracts were less as compare to Oxfendazole. The efficacy of Caesalpinia crista and Nigella sativa was $70.83 \%$ and $57.5 \%$ respectively while the efficacy of Oxfendazole was $90.83 \%$.In vitro treatment at $37 \pm 1{ }^{\circ} \mathrm{C}$ revealed that a serial dose of the plant extract caused dose-dependent vermicidal effect on the worm (significant efficacy at $\mathrm{P}<0.05$ ), except at the lowest dose (i.e. $5 \mathrm{mg} / \mathrm{mL}$ ). The efficacy of drugs was calculated on the basis of reduction in total worm count after treatment.
\end{abstract}

Keywords Anthelmintic, Broiler and Methanol Extract

\section{Introduction}

The increasing demand on poultry products from back yard and commercial poultry systems is restricted by the heavy burden of different poultry parasites which are emerging in such production systems (Fossum et al.[17]). There are emerging several parasitic infections, like
Ascaridia, Heterakis, Subulura and Strongyloides. Ascaridia galli is the most prevalent helminth species in different poultry production systems (Permin et al.[34]; Abdelqader et al.[2]; Kaufmann et al.[27]). Heavily infected chickens may damage the integrity of intestinal mucosa and nutrient utilization can be hampered which decrease weight gain (Kilpinen et al.[29]; Das, et al.[14]). Economic losses are usually associated with Ascaridia galli infection because of treatment cost and impair performance (Ruff.[36]; Martín-Pacho et al.[32]). The chief economic importance lies in the ability of $A$. galli to act as a vector for transmission of other infectious organisms like Salmonella enterica and Escherichia coli (Chadfield et al[13]; Permin et al.[35]).

Despite remarkable achievements in the discovery and improvement of pharmaceutical anthelmintics, diseases due to nematode infections continue to be the greatest constraint in sustainable livestock production worldwide, primarily due to rapid evolution of drug resistance in these parasites to all classes of anthelmintics (Stear et al.[42]). A. galli is a roundworm parasitizing the small intestine of birds, and is by far the most prevalent of all helminths infecting poultry (Permin et al.[34]). A. galli infections continue to be the most debilitating factor impeding poultry productivity resulting in retarded growth, weight loss, diarrhea, poor absorption of nutrients, death and even the spread of fatal bacterial infections (Gauly et al.[19]).

The development of drug resistant helminths against chemotherapeutical products and the associated risks of chemical residues in poultry products have drawn the attention to alternative approaches. Different approaches were employed to sustainable control of A. galli, for example, utilization of genetic resistance (Gauly et al.[18]; Abdelqader et al.[1]; Kaufmann et al.[26]), nutrition of host animal (Das, et al.[14]), biological control (Braga et al.[11]), and the use of plants with anti-parasitic properties (Siamba et al.[40]; Kholhring et al.[28]). For centuries, medicinal plants have been used to combat parasitism, and in many parts of the world. The nicker nut Caesalpinia crista L. (Caesalpiniaceae), a perennial climbing shrub, which is 
distributed worldwide in tropical and subtropical regions suchas southern and western Africa and the Indo-Pakistan subcontinent, and is native in tropical Asia. The leaves have an antifilarial effect (Datt'e et al.[15]) and the seeds are also considered to be effective for the treatment of helminths of sheep (Akhtar and Aslam.[6]). Caesalpinia crista seed powder at the dose rate of $50 \mathrm{mg} / \mathrm{kg}$ body weight, its equivalent methanolic extract and piperazine at dose rate of $200 \mathrm{mg} / \mathrm{kg}$ body weight have similar effectiveness in treating the Ascarid infection of poultry (Javed et al. [25]). Nigella sativa is an annual herb of the Ranunculaceae family, which grows in countries bordering the Mediterranean Sea, Pakistan and India. This widely distributed plant is native to Arab countries and other parts of the Mediterranean region.Nigella sativa have shown efficacy against ovine and caprine helminthiasis in the form of reduction of faecal egg counts without any side effect (Akhtar.[5]). The extracts of $N$. sativa seeds have been used by patients to retard the carcinogenic process (Hassan and El-Dakhakhny.[22]; Worthen et al.[44]), treat abdominal pain, diarrhoea, flatulence and polio (Enomoto et al.[16]), exert antiinflammatory (Chakravarty.[12]; Houghton et al.[24]) and antioxidant effects (Mansour et al.[31]). Besides, the essential oil was shown to have antinematodal (Akhtar and Riffat.[7]), antischistosomal (Mahmoud et al.[30]), antimicrobial (Hanafy and Hatem.[21]; Aboul-Ela et al.[3]) and antiviral (Salem and Hossain.[37]) effects.

The present study encourages the possible use of indigenous plants for the treatment of Ascaridia galli infection in poultry, because these indigenous drugs are cheaper and easily available.

\section{Materials and Methods}

\section{Feeding, management and grouping of birds}

A total of one hundred and thirty day-old broiler chicks were procured from a local hatchery. The birds were reared under standard environmental condition for 45 days. The birds were fed with a local poultry feed named Big Bird feed. The birds were divided randomly into five groups namely A, B, C, D and E.Each group had 26 birds. Group A and E were positive and negative controls while group $\mathrm{B}, \mathrm{C}$ and $\mathrm{D}$ were treated with Caesalpinia crista, Nigella sativa and Oxfendazole respectively.

\section{Source of Infection}

Infected intestinal contents were collected from the poultry meat sale shops, poultry farms (layer farms) and hotels where birds were slaughtered. These intestines were processed in the laboratory of the Department of Clinical Medicine and Surgery, University of Veterinary and Animal Sciences, Lahore, Pakistan. On 15th day of experiment, four groups were infected orally with Ascardia galli while group E was kept as control. On 25th day post-infection before treatment, four birds from each group including control were randomly selected and slaughtered. The intestines were examined by setting and decanting method. The worms obtained from the birds of each group (except non-infected non-medicated) were counted (Ashraf.[10]. After the confirmation of development of the infection on the 25th day post infection, all the bird of the group $\mathrm{B}$ and $\mathrm{C}$ were treated orally with Caesalpinia crista and Nigella sativa at the dose rate of $50 \mathrm{mg} / \mathrm{kg}$ each. Group D was fed Oxfendazole at the rate of $10 \mathrm{mg} / \mathrm{kg}$ body weight in drinking water. At 30th day post-infection, all birds were slaughtered and above mentioned procedure were adapted to count worms.

\section{Collection of Worms}

Mature worms were collected from the intestines of naturally infected chicken. Adult female were identified on the basis of size and absence of spicules (Souslby.[41]).

\section{Collection of Experimental Ova}

Ova of the worms were obtained by splitting open the female worms to liberate eggs. Uteri were chopped with scissors and water was added to make the suspension. The suspension was poured through wire mash screen and material on the screen was discarded. The suspension was again poured through a wire mash screen. The eggs were resuspended in a $2 \%$ formalin solution to prevent contamination as described by Permin et al.[33].

\section{Preparation and Administration of Herbal Drugs}

Seeds of Caesalpinia crista and Nigella sativa were purchased from local herbal market of Lahore then these seeds were dried in a hot air oven at $50^{\circ} \mathrm{C}$. The dried seeds were macerated to fine powder and then refluxed with methanol $(100 \mathrm{~g} / \mathrm{L})$ for $8 \mathrm{~h}$ at $60^{\circ} \mathrm{C}$. The solution obtained was filtered through Whatman filter paper (No. 1) and the solution was evaporated to complete dryness at $50^{\circ} \mathrm{C}$. The methanol extract was obtained as a deep brown powdered material, which was then refrigerated at $4^{\circ} \mathrm{C}$ until further in vitro use. $1 \mathrm{~h}$ prior to in vitro assay, a stock concentration of the extract, $80 \mathrm{mg} / \mathrm{mL}$, was prepared by dissolving in $0.9 \%$ neutral phosphate-buffered saline (PBS, $\mathrm{pH} \sim$ 7.1) supplemented with $1 \%$ dimethylsulfoxide (DMSO). Varying doses, viz. 5, 10, 20 and $40 \mathrm{mg} / \mathrm{L}$, were then prepared by serial dilution of the stock solution using PBS with DMSO. The methanolic extract of Caesalpinia crista and Nigella sativa powder was prepared using a Soxhlet apparatus (Javed.[25]) for in vivo use.The evaporated extract representing $50 \mathrm{mg} / \mathrm{kg}$ body weight of powder was administered orally to chicks individually (Akhter.[5]).

\section{Synthetic Drug "Oxfendazole" (Systamex ICI Pakistan Ltd.)}

Oxfendazole was medicated in the form of drench given per oral solution at the dose rate of $10 \mathrm{mg} \mathrm{kg}$ body weight (Georgi et al.[20]). The reductions in the worms count and body weight gain were recorded for each group.

\section{Statistical Analysis}


The data was presented by mean and standard error of means. Increase or decrease in worm count was presented by percentage. The data collected from this experiment were statistically analyzed by applying analysis of variance test and significance difference was determined using Least Significant Difference (Steel and Torrie.[43]).

\section{Results and Discussion}

Ascaridia galli in the control experiment survived for $97.73 \pm 0.90 \mathrm{~h}$ in a medium composed only of PBS with $1 \%$ DMSO. The nematodes thrived relentlessly, but once their movement ceased, death ensued abruptly.Figure-1 Presents the response in physical activity of the nematodes after treatment with a broad-spectrum antiparasitic drug, Oxfendazole, and the extracts of Caesalpinia crista,Nigella sativa at the doses of $5,10,20,40$ and $80 \mathrm{mg} / \mathrm{mL}$, respectively. Oxfendazole was found to be a highly effective nematocide exerting profound dose-dependent activity at all doses tested. The plant extract also indicated concentration-dependent efficacy on the nematode. However, at the lowest concentration, i.e. $0.5 \mathrm{mg} / \mathrm{mL}$, the nematodes did not show any significant mortality with respect to the control, although average death was observed earlier than those in control group. Figure 1 shows the comparative efficacy of the drug and the plant extract, depicting dose-dependent activity for both cases.

In our vivo experiment, Caesalpinia crista seed powder was fed to the birds on 25th day post-infection. At 30th day post-infection, the anthelmintic efficacy of Caesalpinia crista was found to be $57.05 \%$. Shaker et al.[39]reported that Caesalpinia crista at the dose rate of $0.4 \mathrm{~g} / \mathrm{kg}$ body weight reduced worm count by $96.07 \%$ in turkey pullets against intestinal nematodes. Similarly, Akhtar.[8]showed that anthelmintic efficacy of Caesalpinia crista at the dose rate of $50 \mathrm{mg} / \mathrm{kg}$ body weight against Ascaridia galli. The findings of our study are in contrast to the results of Javed et al. [25] and Akhtar. [5]. The differences in the results may be due to difference in experimental procedures, dose rate, and infectivity. The drug efficacy of Nigella sativa was found to be 56.59\%. Akhter et al.[5] reported that Nigella sativa reduced ovine and caprine helmenthiasis without any side effects. Similarly, Aboul Ela and Al-Homidan et al.[4] reported that Nigella sativa reduced fecal count by $88 \%$ and $86 \%$ respectively.

The body weight of different experimental groups A, B,C,D \& E were recorded and results shown that there was no significant difference in weight gain amongst treated groups on $15^{\text {th }} \& 30^{\text {th }}$ day post infection, while there is significant difference in weight gain of infected non medicated group and medicated groups(Table-2).These body weights completely correlates with the results of Shaker et al 2011 where he reported that alendazole and caesalpinia crista treated groups had no significant body weights difference at $28^{\text {th }}$ and 42 days of age in turkey poults infected with heterakis gallinarium, body weights at $28^{\text {th }}$ and 42 days of age were $947.33 \pm 8.09,951.27 \pm 8.45$ and $2235.33 \pm$ $7.41,2292.34 \pm 7.79$ respectively.body weight was significantly different in infected non medicated group and body weights were $757.47 \pm 2.82$ and $1392.00 \pm 15.19$ at 28th and 42 days of age. ABZ and ACEA treatments exerted beneficial effects by significantly improving body weight gain and feed conversion ratio values compared to the positive control group. Moreover, ACEA significantly ( $\mathrm{P} \leq$ 0.05 ) enhanced growth performance of turkey poults than that of ABZ. Comparable to our results, A. herb-alba improved the growth performance of chickens infested with A. galli (Seddiek et al.[38])

Table 1. Mean worm count after infection and before treatment on $25^{\text {th }}$ day and $30^{\text {th }}$ day post

\begin{tabular}{|c|c|c|c|}
\hline Groups & Post infection $\left(\mathbf{2 5}^{\text {th }}\right.$ day) & Post treatment $\left(\mathbf{3 0}^{\text {th }}\right.$ day) & $\begin{array}{c}\text { Percent decrease or } \\
\text { increase }\end{array}$ \\
\hline A & $23 \pm 8$ & $33 \pm 8$ & 30.29 (Increase) \\
\hline B & $14 \pm 7$ & $6 \pm 3$ & 57.05 (Decrease) \\
\hline C & $32 \pm 9$ & $14 \pm 6$ & 56.59 (Decrease) \\
\hline D & $45 \pm 8$ & $6 \pm 4$ & 87.50 (Decrease) \\
\hline E & $0 \pm 0.00$ & $0 \pm 0.00$ & 0.00 (Decrease) \\
\hline
\end{tabular}

A: Infected nonmedicated B: Caesalpinia crista C: Nigella sativa

D: oxfendazole E: Non infected non medicated

Table 2. weight gain in broilers after infection and treatment

\begin{tabular}{|c|c|c|}
\hline Groups & Post infection $\left(\mathbf{1 5}^{\text {th }}\right.$ day) & Post treatment $\left(\mathbf{3 0}^{\text {th }}\right.$ day) \\
\hline A & $795 \pm 15.83^{\text {d }}$ & $1720 \pm 22.5^{\text {c }}$ \\
\hline B & $975 \pm 16.83^{\mathrm{b}}$ & $1889 \pm 11.9^{\mathrm{b}}$ \\
\hline C & $945 \pm 14.83^{\mathrm{c}}$ & $1846 \pm 21.15^{\mathrm{b}}$ \\
\hline D & $982 \pm 12.83^{\mathrm{b}}$ & $1897 \pm 11.94^{\mathrm{b}}$ \\
\hline E & $1060 \pm 18.83^{\mathrm{a}}$ & $1960 \pm 12.96^{\mathrm{a}}$ \\
\hline
\end{tabular}

${ }^{\mathrm{a}-\mathrm{d}}$ Mean values having similar alaphabets differ significantly $(\mathrm{P}<0.05)$

A: Infected nonmedicated B: Caesalpinia crista C: Nigella sativa

D: oxfendazole E: Non infected non medicated 


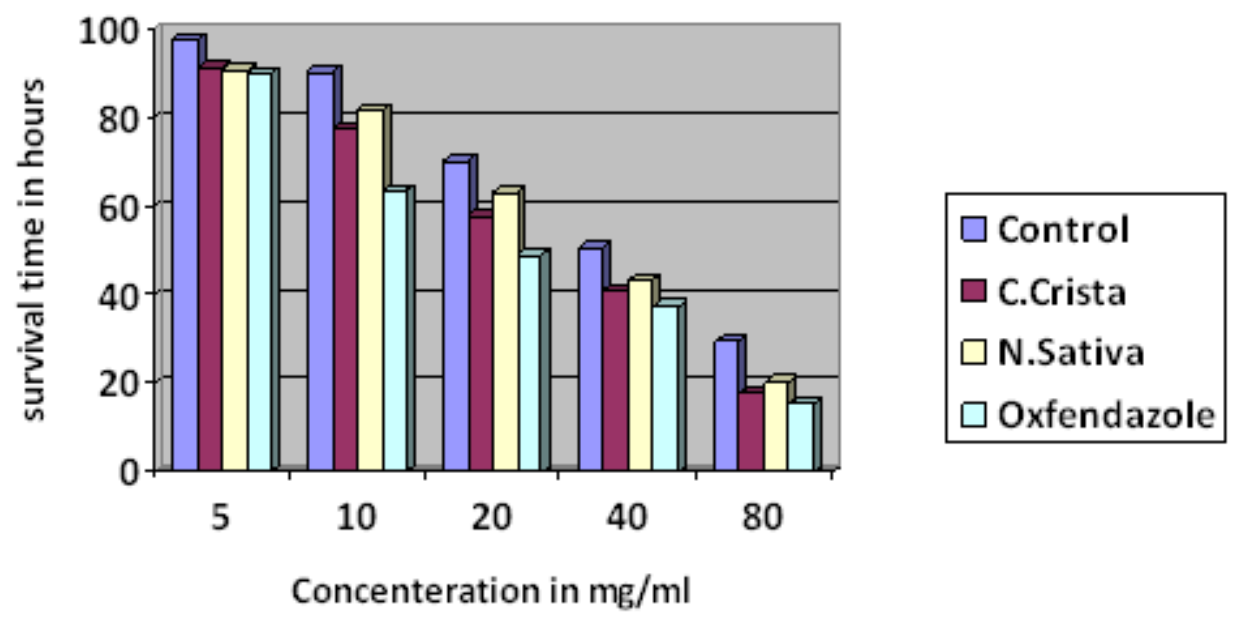

Figure 1. Comparison of the Efficacy of Oxfendazole and the Extract of Caesalpinia Crista and Nigella Sativaon the Survival of a. Galli In Vitro

\section{REFFERENCES}

[1] Abdelqader, A., Gauly, M., Wollny, C.B.A., 2007. Response of two breeds of chickens to Ascaridia galli infections from two geographic sources.Vet. Parasitol. 145, 176-180.

[2] Abdelqader, A., Gauly, M., Wollny, C.B., Abo-Shehdada, M.N., 2008. Prevalence and burden of gastro-intestinal helminths among local chickens in northern Jordan. Prev. Vet. Med. 85, 17-22.

[3] Aboul Ela MA, El-Shaer NS, Ghanem NB. (1996) Antimicrobial evaluation and chromatographic analysis of some essential and fixed oils. Pharmazie 51:993-4.

[4] Aboul-Ela, E.I. (2002). Cytogenetic studies on Nigella sativa seeds extract and thymoquinone on mousecells infected with schistosomiasis using karyotyping. Mutat Res., 516(1-2): 11-17.

[5] Akhtar, M.S. (1986). Anthelmintic evaluations of indigenous medicinal plants for veterinary usage. $3^{\text {rd }}$ progress Report of the PARC, Research project. Univ. of Agric., Faisalabad.

[6] Akhtar, M.S., Aslam, M., 1989. Field trial of Karanjwa seedsagainst nematodes in sheep. Pak. J. Agric. Res. 10, 175-178.

[7] Akhtar MS, Riffat S. (1991) Field trial of Saussurea lappa roots against nematodes and Nigella sativa seeds against cestodes in children. J Pak Med Assoc 41:185-7.

[8] Akhtar MS, Iqbal Z, Khan MN and Lateef M 2000. Anthelmintic activity of medicinal plants with particular reference to their use in animals in the Indo Pakistan subcontinent. Small Ruminant Research 38, 99-107.

[9] Al-Homidan, A., A.A. Al-Qarawi, S.A. Al-Waily and S.E. Adam (2002). Response of broiler chicks todietary Rhazya stricta and Nigella sativa. Brit. Poult. Sc., 43(2): 291-296. -

[10] Ashraf, M. (1980). Anthelmentic efficacy of phenothiazine piperazine, Levamisole and Babarang against mature and immature stages of Ascaridia galli and Heterakis galinarium in chicken.M.Sc(Hons.)Thesis, Univ. Agric. (CVS),
Faisalabad.

[11] Braga, F.R., Araújo, J.V., Araujo, J.M., Frassy, L.N., Tavela, A.O., Soares, F.E.F., Carvalho, R.O., Queiroz, L.M., Queiroz, J.H., 2011. Pochonia chlamydosporia fungal activity in a solid medium and its crude extract against eggs of Ascaridia galli. J. Helminthol. 85, 1-5.

[12] Chakravarty N. (1993) Inhibition of histamine release from mast cells by nigellone. Ann Allergy 70:237-42.

[13] Chadfield, M., A. Permin, P. Nansen and M. Bisgaard, 2001, Investigation of the parasitic nematode Ascaridia galli (Shrank 1788) as a potential vector for Salmonella entericadissemination in poultry. Parasitol Res (2001) 87: 317-325.

[14] Das.G., Kaufmann, F., Abel, H., Gauly, M., 2010. Effect of extra dietary lysine in Ascaridia galli-infected grower layers. Vet. Parasitol. 170, 238-243.

[15] Datt'e, J.Y.,Yapo, P.A.,Kouam'e-Koffi, G.G., Kati-Coulibaly, S., Amoikon, K.E., Offoumou, A.M., 2004. Leaf extract of Caesalpinia bonduc Roxb. (Caesalpiniaceae) induces an increase of contractile force in rat skeletal muscle in situ. Phytomedicine 11, 235-241.

[16] Enomoto S, Asano R, Iwahori Y, Narui T, Okada Y, Singab AN, Okuyama T. (2001) Hematological studies on black cumin oil from the seeds of Nigella sativa L. Biol Pharm Bull 24:307-10.

[17] Fossum, O., Désirée, S.J., Pernille, E.E., Vågsholm, I., 2009. Causes of mortality in laying hens in different housing systems in 2001 to 2004. Acta Vet. Scand. 51, 3-12.

[18] Gauly, M., Bauer, C., Preisinger, R., Erhardt, G., 2002. Genetic differences of Ascaridia galli egg output in laying hens following a single dose infection. Vet. Parasitol. 103, 99-107.

[19] Gauly M, Duss C, Erhardt G. Influence of Ascaridia galli infections and anthelmintic treatments on the behaviour and social ranks of laying hens (Gallus gallus domesticus). Vet Parasitol 2007; 146:271-280.

[20] Georgi, M., P.K. Waler, R.A. Grisp and W.S. Walmer (1990). Chemothrapeutic trials of oxfendazoleand albendazole against $A$. galli in chickens. Brit. Vet. J. Anim. Sci., 0(409-412). 
[21] Hanafy MS, Hatem ME. (1991) Studies on the antimicrobial activity of Nigella sativa seed (black cumin). J Ethnopharmacol 34:275-8.

[22] Hassan M, El-Dakhakhny M. (1992) Effect of some Nigella sativa constituents on chemical carcinogenesis in hamster cheek pouch. J Egyptian Soc PharmacolExp Therap 11:675-7.

[23] Hassan, Z. (1966). Investigation into the helminth infection in country fowl. Pak. J. Sci., 18: 307-309.

[24] Houghton PJ, Zarka R, De las Heras B, Hoult RS. (1995) Fixed oil of Nigella sativa and derived thymoquinone inhibit eicosanoid generation in leukocytes and membrane lipid peroxidation. Planta Medica 61:33-6.

[25] Javed, I., Akhtar, M.S., Rahman, Z.U., Khaliq, T., Ahmad, M.,1994. Comparative anthelmintic eficacy and safety ofCaesalpinia crista seed and piperazine adipate in chickens with artificially induced Ascaridia galli infection. Acta Vet. Hungarica 42, 103-109.

[26] Kaufmann, F., Das, , G., Preisinger, R., Schmulz, M., König, S., Gauly, M., 2011a. Genetic resistance to natural helminth infections in two chicken layer lines. Vet. Parasitol. 176, 250 257.

[27] Kaufmann, F., Das, , G., Sohnrey, B., Gauly, M., 2011 b. Helminth infections in laying hens kept in organic free range systems in Germany. Livest. Sci. 141, 182-187.

[28] Kholhring, L., Bishnupada, R., Kumar, D.B., 2009. Anthelmintic activity of Acacia oxyphylla stem bark against Ascaridia galli. Pharm. Biol. 47, 578-583.

[29] Kilpinen, O., Roepstorff, A., Permin, A., Nørgaard-Nielsen, G., Lawson, L.G., Simonsen, H.B., 2005. Influence of Dermanyssus gallinae and Ascaridia galli infections on behavior and health of laying hens (Gallus gallus domesticus). Br. Poult. Sci. 46, 26-34.

[30] Mahmoud MR, El-Abhar HS, Saleh S. (2002) The effect of Nigella sativa oil against the liver damage induced by Schistosoma mansoni infection in mice. J Ethnopharmacol 79:1-11.

[31] Mansour MA, Nagi MN, El-Khatib AS, Al-Bekairi AM. (2002) Effects of thymoquinone on antioxidant enzyme activities, lipid peroxidation and DT-diaphorase in different tissues of mice: a possible mechanism of action. Cell. Biochem. Funct. 20:143-51.

[32] Martín-Pacho, J.R., Montoya, M.N., Aranguena, T., Toro, C., Morchon, R., Marcos-Atxutegi, C., Simon, F., 2005. A coprological and serological survey for the prevalence of
Ascaridia spp. in laying hens. J. Vet. Med. B Infect. Dis. Vet. Public Health 52, 238-242.

[33] Permin, A., P. Nansen, M. Bisgaard, F. Frandson and M. Pearman (1997). Studies on Ascaridia galli inchickens kept at different stocking rates. Avian Pathol.27(4): 382-387.

[34] Permin, A., Bisgaard, M., Frandsen, F., Pearman, M., Kold, J., Nansen, P., 1999. The prevalence of gastrointestinal helminths in different poultry production systems. Br. Poult. Sci. 40, 439-443.

[35] Permin, A., Christensen, J.P., Bisgaard, M., 2006. Consequences of concurrent Ascaridia galli and Escherichia coli infections in chickens. Acta Vet. Scand.47, 43-54.

[36] Ruff, M.D., 1999. Important parasites in poultry production systems. Vet.Parasitol. 84, 337-347.

[37] Salem ML, Hossain MS. (2000) Protective effect of black seed oil from Nigella sativa against murine cytomegalovirus infection. Int J Immunopharmacol 22(9):729-40.

[38] Seddiek SHA, Mobarak MA, Mobarak AA (2007). The effect of Artemisia herba alba on chickens infested with Ascaridia galli in comparison with piperazine citrate. Mansura Vet. Med. J., 9: 165-178

[39] Shaker A. Seddiek1, Mohamed M. Ali2, Hanem F. Khater3* and Mohamed M. El-Shorbagy(2011), Anthelmintic activity of the white wormwood, Artemisia herba-alba against Heterakis gallinarum infectingturkey poults, Journal of Medicinal Plants Research Vol. 5(16), pp. 3946-3957

[40] Siamba, D.N., Okitoi, L.O., Watai, M.K., Wachira, A.M., Lukibisi, F.B.,Mukisira, E.A., 2007. Efficacy of Tephrosia vogelli and Vernonia amygdalina as anthelminthics against Ascaridia galli in indigenous chicken.Livestock Research for Rural Development. 19 (12), Article \#176. Retrieved October 19, 2011, fromhttp://www.lrrd.org/lrrd19/12/siam19176.htm.

[41] Soulsby, E.J.L. (1982). Helminths, arthropodes and protozoa of domestic animals. Baillere Tindall,London, pp 163-164. 774-776.

[42] Stear MJ, Doligalska M, Donskow-Schmelter K. Alternatives to anthelmintics for the control of nematodes in livestock. Parasitology 2007; 134:139-151.

[43] Steel, R.G.D. and J.H. Torrie (1982). Principles and Procedures of Statistics. 2nd Ed., McGrawHill Books, New York, pp. 137-171.

[44] Worthen D, Ghosheh O, Crooks P. (1998) The in vitro anti-tumor activity of some crude and purified components of black seed, Nigella sativa L. Anticancer Res 18:1527-32. 